\title{
A influência da mídia nos processos judiciais criminais ${ }^{1}$
}

Deise Araujo Barbosa ${ }^{2}$

\section{RESUMO}

objetivo do presente artigo é abordar a influência dos meios de comunicação na propagação de notícias acerca de crimes e do seu respectivo processamento perante a justiça criminal. Para ilustração, partiremos de uma análise da repercussão social do crime conhecido nos EUA como "A Corredora do Central Park", o qual foi retratado na minissérie produzida pela Netflix, denominada "Olhos que condenam".

Palavras-chaves: Mídia. Influência. Processo Criminal. Corredora do Central Park. Cinco do Central Park.

\section{INTRODUÇÃO}

A série "Olhos que Condenam" (sob título original "When they see us", lançada em 31 de maio de 2019), do serviço de streaming Netflix, retrata um típico caso em que a mídia, instigando o clamor público, exerceu forte influência na condução de um julgamento de crimes de estupro e de tentativa de homicídio, supostamente praticados por cinco jovens.

A minissérie, constituída de apenas quatro capítulos surpreendentemente intensos, aborda o processo criminal que ficou conhecido

1 Data de Recebimento: 10/08/2019. Data de Aceite: 20/09/2019.

2 Servidora Pública do Ministério Público do Estado do Ceará. Mestranda em Direito Constitucional pela Universidade Federal do Ceará. Pós-Graduada em Direito Público pela Unice - Ensino Superior. Graduada em Direito pela Universidade Federal do Ceará. E-mail: deiseab@yahoo.com.br 
nos Estados Unidos como "o caso da corredora do Central Park".

Na madrugada de 19 de abril de 1989, Trisha Meili, uma jovem loira de 28 anos, foi brutalmente estuprada e violentada no Central Park, em Nova Iorque.

Na mesma ocasião, véspera de um feriado escolar, dezenas de adolescentes negros e latinos, de baixa renda, estavam fazendo baderna nas imediações, apedrejando ciclistas, batendo em corredores e roubando mendigos. Por esta razão, cinco deles, com idade entre 14 e 16 anos, foram detidos - Kevin Richardson, Yusef Salaam, Raymond Santana, Antron McCray e Korey Wise - e encaminhados à Delegacia.

O resultado da malfadada atuação policial nas investigações culminou na responsabilização dos jovens também pelo crime de estupro da jovem corredora. Segundo se apurou posteriormente, uma vez detidos, os adolescentes foram induzidos pelas autoridades policiais a confessar o crime, sendo submetidos a um exaustivo e torturante interrogatório de mais de trinta horas, sem alimentação.

No caso real, o vídeo produzido e utilizado como prova da confissão dos acusados revelou adolescentes reprimidos, reproduzindo respostas vagas, limitadas a afirmar ou negar os questionamentos feito pelas autoridades, de maneira que nenhum deles soube descrever detalhes do crime - como as características da vítima ou especificamente o local do crime.

O fato é que, à época, as circunstâncias do crime provocaram grande revolta social e repercussão midiática. A sociedade, a mídia e a imprensa pressionavam o sistema criminal a uma resposta, possivelmente como forma de superar a sensação de terror instalada.

Afora as discussões de cunho social que envolveram o caso - tais como a influência do fator racial tanto da vítima, quanto dos supostos agressores - é inegável a participação da imprensa e da mídia como fermento da acusação judicial dos jovens. 


\section{A INFLUÊNCIA DA MÍDIA NO PROCESSO CRIMINAL}

No dia 22 de abril de 1989, o Daily News publicou notícia em primeira página que vinculava definitivamente os jovens ao crime: "'Wilding' teens held in rape: seven are called part of wolf pack".

Donald Trump, à época empresário bilionário, em $1^{\circ}$ de maio de 1989, manifestou-se em uma página inteira no jornal The New York Times, declarando, entre suas palavras: "It's more than anger. It's hatred, and I want society to hate them" ${ }^{3 \prime}$.

É inegável que, em se tratando da praxis jurídica, ambiente impregnado, de um lado, de conceitos de difícil compreensão e, de outro, de relevante interesse social, a mídia exerce papel aproximativo entre a tecnicidade jurídica e a compreensão popular. A crônica jurídica é a atividade dos meios de comunicação, que consiste na veiculação de informações acerca dos trâmites processuais do Poder Judiciário, como instrumento pelo qual os atos tornam-se não somente públicos, mas também acessíveis à população.

Ocorre que, na maioria das circunstâncias, a atividade midiática é exercida por leigos do Direito, os quais conhecem o processo criminal muito elementarmente. É comum, por exemplo, os meios de comunicação noticiarem uma prisão temporária ou cautelar de uma determinada pessoa, elevando a decisão judicial à categoria de definitivo.

A veiculação de notícias inexatas produz consequências terríveis ao processo, principalmente em relação ao acusado, que se vê estigmatizado como bandido antes mesmo de qualquer condenação definitiva, tendo a sua presunção de inocência e todas as demais garantias constitucionais processuais fortemente violadas.

Por outro lado, muitas vezes, o posicionamento acusador da imprensa é proposital. Um método comum de veicular notícias e atrair

3 "É mais do que raiva. É ódio, eu quero que a sociedade os odeie" (Tradução nossa). 
o interesse dos espectadores pelos meios jornalísticos é o sensacionalismo, consistente num modo de veicular a notícia que extrapola os lindes do fato realmente ocorrido, caracterizada por ausência de moderação, de maneira a chocar o público e lhe causar maior envolvimento emocional. Nesse modelo informativo, tornam-se difusos os limites do real e do imaginário (VIEIRA, 2003, p. 52-53).

A influência perniciosa exercida pelos meios de comunicação manifesta-se, também, pelos fatos que estes deixam de enunciar, além daqueles efetivamente expostos, alienando o espectador a um olhar unilateral do problema noticiado, gerando neste uma cólera punitiva e furtando ao investigado o direito de voz.

Mais além, uma vez promovendo uma verberação do acusado como criminoso antes mesmo de qualquer condenação definitiva, tal prejulgamento é suficiente para influenciar o convencimento do juiz penal e, consequentemente, o resultado de suas decisões.

De fato, quando esse prejulgamento ocorre, estamos ante um juízo paralelo que pode afetar a imparcialidade do juiz e todo o direito ao devido processo legal (SANGUINÉ, 2001, p. 268), influenciando-o inconscientemente a avaliar a prova dos autos de forma tendenciosa, ou o convencendo da culpabilidade do acusado logo de imediato. De maneira que este exame superficial, muitas vezes permeado de valores extrajurídicos, dificilmente será derrubado pelas provas apresentadas no processo.

Por outro lado, mesmo que essa influência não seja suficiente para orientar diretamente o juiz, em alguns casos desempenham uma pressão implícita na sua consciência, levando-o a agir de acordo com o que pensa que lhe é esperado para satisfazer o clamor público, ou por receio de represálias, mesmo sem que a mídia se manifeste expressamente nesse sentido.

Essa pressão ainda pode afigurar-se real, tacitamente (quando a mídia opina, por exemplo, que seria a melhor alternativa o juiz prender preventivamente um referido acusado) ou expressamente 
(quando suplica diretamente, através dos meios de comunicação social, que o juiz tome esta providência)".

Devido a esta grande influência exercida pela mídia sobre as decisões tomadas pelo Poder Judiciário, originou, nos Estados Unidos, a expressão "trial by media", que consiste nesse prejulgamento realizado pela imprensa, por suas manifestações. Nestas, formulam-se juízos de valor a respeito dos fatos, de um lado sustentando a culpa do acusado e defendendo sua rápida condenação e, de outro, criticando a forma permissiva e leniente como a justiça conduz o caso (SCHREIBER, 2010, p. 347).

Quando se trata de crimes cujo julgamento é submetido ao Tribunal do Júri, tal como o caso dos "Cinco do Central Park", a influência midiática tem ainda maior relevo. Em geral, o julgamento popular inevitavelmente envolve uma maior comoção social e implica um maior envolvimento de valores morais e éticos.

Esse elo mais forte entre o Tribunal do Júri e a mídia ocorre porque naquele há um forte apelo junto à opinião pública. Mães de vítimas que pranteiam durante a sessão de julgamento; advogados que anunciam novos fatos bombásticos, capazes até de mudar o curso do processo; grupos organizados que mobilizam protestos, com faixas, cartazes e alto-falantes, defronte ao prédio do fórum, e exigindo a condenação ou "o que é menos corrente" a absolvição do réu (OLIVEIRA, 2000, p. 41).

Ademais, a limitação técnico-jurídica que recai sobre o corpo de jurados, pessoas comuns da sociedade, subtrai-lhes ainda mais o equilíbrio e o discernimento para filtrar o que foi reiteradamente incutido em seus pensamentos antes do julgamento do processo que irão decidir. Dificilmente um jurado consegue manter-se isento diante da pressão da mídia e do prévio julgamento "extrajudicial" transmitido diariamente para suas casas (PRATES; TAVARES, 2008, p. 33-39).

No caso dos "Cinco do Central Park", em uma coluna de opinião intitulada "Os bárbaros estão vencendo", o jornal "Washington Post" 
publicou: "How does a civilized, self-confident people deal with enemies who gang-rape their women? Armies stand them up against a wall and shoot them; or we hang them" ${ }^{\prime \prime}$, em uma típica postura condenatória.

As evidências contra a autoria imputada aos acusados eram notórias - o exame de DNA do sêmen no corpo da vítima não foi compatível com nenhum deles, a dinâmica dos fatos descrita nos seus depoimentos não se encaixava e o horário e o local do crime não eram compatíveis.

Ainda assim, em 1990, os Cinco do Central Park foram condenados. Os quatro menores de dezesseis anos foram sentenciados a sete anos de prisão. Korey Wise, que já contava com dezesseis anos na época do crime, recebeu pena de maior de idade, passando treze anos na prisão.

A constatação da inocência deles sobreveio apenas no ano de 2002, quando Matias Reyes, que cumpria pena de prisão perpétua na mesma penitenciária de Wise por uma série de estupros que praticou naquele mesmo ano de 1989, assumiu a autoria do crime, tendo sido sua confissão harmonizada com a compatibilidade das marcas das unhas e do DNA encontrado nas vestes da vítima.

\section{CONCLUSÃO}

Por todo o exposto, entendemos que, uma vez que o Direito Penal trata das matérias mais fundamentais da sociedade, abarcando os assuntos de maior relevância social, entendermos ser primordial para a manutenção de uma sociedade democrática a propagação da informação dos crimes e da atuação da Administração da Justiça sobre eles.

Contudo, proporcionar informação é diferente de realizar julga-

4 "Como um povo civilizado e autoconfiante lida com inimigos que estupram suas mulheres em gangues? Exércitos os colocam contra a parede e atiram neles; ou nós os enforcamos" (Tradução nossa). Cf.: Revisiting the Central Park Five case in the \#MeToo era". Disponível em: https://www.wsws.org/ en/articles/2019/06/08/pers-j08.html. Acesso em: 02/08/2019. 
mentos. É preciso, portanto, partir de uma distinção entre informação sobre o fato e realização de valor com caráter prévio como antecipação da conclusão do processo, de maneira a respeitar os limites da ingerência da pressão social sobre o exame técnico-jurídico dos fatos.

\section{THE INFLUENCE OF MEDIA IN CRIMINAL LEGAL PROCEEDINGS}

\section{ABSTRACT}

This article aims to broach the influence of the media on the spread of news about crimes and their processing in criminal justice. For illustration, we will start from an analysis of the social repercussion about the crime called in the USA as "Central Park Jogger", which was portrayed in the miniseries produced by Netflix "When they see us".

Keywords: Media. Influence. Criminal process. Central ParkJogger. Central Park Five.

\section{BIBLIOGRAFIA}

PRATES, Flávo Cruz; TAVARES, Neusa Felipim dos Anjos. A influência da mídia nas decisões do conselho de sentença. Revista Direito e Justiça. Porto Alegre, v. 34, n. 2, p. 33-39, jul/dez. 2008.

OLIVEIRA, Marcus Vinícius Amorim de. O tribunal do júri popular e a mídia. Revista Jurídica Consulex, Brasília, v. 4, n. 38, fev. 2000.

SCHREIBER, Simone. A publicidade opressiva dos julgamentos criminais. Rio de Janeiro. Editora Renovar, 2010.

DOMINGUEZ, Daniela Montenegro Mota. A influência da Mídia nas decisões do Juiz penal. Disponível em: http://www.revistas.unifacs.br/index. php/redu/article/view/507. Acesso em: 05 ago. 2019.

VIEIRA, Ana Lúcia Menezes. Processo penal e mídia. São Paulo: Revista dos Tribunais, 2003. 
SANGUINÉ, Odone. A inconstitucionalidade do clamor público como fundamento de prisão preventiva. In: SHECARIA, Sérgio Salomão (Org.). Estudos Criminais em Homenagem a Evandro Lins e Silva (criminalista do século). São Paulo: Método, 2001. 